\title{
Models for Force Control in Telesurgical Robot Systems
}

\author{
Árpád Takács ${ }^{1 *}$, Levente Kovács ${ }^{2 *}$, Imre J. Rudas ${ }^{1}$, \\ Radu-Emil Precup ${ }^{3}$, Tamás Haidegger ${ }^{1,4}$
}

${ }^{1}$ Óbuda University, Antal Bejczy Center for Intelligent Robotics, Kiscelli u. 82, H-1032 Budapest, Hungary

${ }^{2}$ Óbuda University, Physiological Controls Group, Bécsi út 96/b, H-1034

Budapest, Hungary

${ }^{3}$ Politehnica University of Timisoara, Department of Automation and Applied Informatics, Bd. V. Parvan 2, RO-300223 Timişoara, Romania

${ }^{4}$ Austrian Center For Medical Innovation and Technology, Viktor-Kaplan-Straße 2, A-2700 Wiener Neustadt, Austria

*corresponding authors

\{arpad.takacs, imre.rudas, tamas.haidegger\}@irob.uni-obuda.hu, kovacs.levente@nik.uni-obuda.hu,radu.precup@upt.ro

Abstract: Surgical robotics is one of the most rapidly developing fields within robotics. Besides general motion control issues, control engineers often find it challenging to design robotic telesurgery systems, as these have to deal with complex environmental constrains. The unique behavior of soft tissues requires special approaches in both robot control and system modeling in the case of robotic tissue manipulation. Precise control depends on the appropriate modeling of the interaction between the manipulated tissues and the instruments held by the robotic arm, frequently referred to as the tool-tissue interaction. Due to the nature of the physiological environment, the mechatronics of the systems and the time delays, it is difficult to introduce a universal model or a general modeling approach. This paper gives an overview of the emerging problems in the design and modeling of telesurgical systems, analyzing each component, and introducing the most widely employed models. The arising control problems are reviewed in the frames of master-slave type teleoperation, proposing a novel soft tissue model and providing an overview of the possible control approaches.

Keywords: surgical robotics; force control; tissue modeling; teleoperation; time delay control 


\section{Introduction}

Healthcare services that are performed or supported by robots from long distances have opened new frontiers in diagnosis and surgery. The initial idea of teleoperation first appeared at NASA in the early 1970s [1]) The idea telesurgery was born in the concept of space exploration. Although the concept of telesurgery in space has never been implemented in real applications, several simulations and research projects have led the development to breakthrough in 2001, when the first intercontinental telesurgical procedure was carried out between the USA and France, based on ISDN communication [2]) The successful procedure proved that theoretically, in special, urgent cases, doctors and surgeon could contact and reach out for patients thousands of kilometers away.

It is most likely that in the near-future, the research and development of telesurgical applications will focus on applications in remote, rural and dangerous areas such as war zones or contaminated sectors. It is evident that the difference between surgical procedures on Earth and in space environments is vast, in terms of complexity. During the past decade, several remote surgery experiments were conducted by NASA on Earth, under extreme conditions. The experiments took place in the world's only permanent undersea laboratory, NEEMO (NASA Extreme Environment Mission Operations), concluding their latest project on September 13, 2014.

Existing issues in telesurgery include the modeling and control challenges of both master and slave sides, while the communication with the surgical crew on Earth creates further issues to address. Most of the difficulties in teleoperation are caused by signal latency and lagging. With the increase of the distance between the master and slave sides, these effects are magnified. Many disturbing effects can be reduced in a general teleoperation surgical robotic system by a well-chosen system architecture and proper control methods. A detailed review article about the current capabilities in surgical robotics, primarily focusing on teleoperated systems was published by Hoeckelmann et al. [4], while available options and a proposed control and modeling framework for telesurgical applications was proposed by Jordán et al. in [5].

One of the major issues of currently available telesurgical systems is the lack of reliable haptic feedback, leaving surgeons to only rely on their visual sensing during procedures. The aim of this work is to give an overview of the concept of telesurgery, approaching the problem from the modeling point of view, addressing the effect of force control and the role of modeling. In Section 2, a state of the art overview is given about telesurgery today, Section 3 briefly presents the components of a telesurgical system, addressing some issues and modeling approaches. Section 4 describes the problem of tool-tissue interaction, giving a thorough summary of the most relevant models found in the literature, with special attention to the available soft tissue models and approaches. 


\section{State of the Art}

Today, the da Vinci Surgical System by Intuitive Surgical Inc. (Sunnyvale, CA) is the best-known and most popular surgical robot system, functioning as a teleoperated manipulator. As of March 31, 2015, there was an installed base of 3,317 units worldwide: 2,254 in the United States, 556 in Europe, 194 in Japan, and 313 in the rest of the world [6]. In the case of the da Vinci, the system is not used routinely for long-distance procedures and interventions. Primarily due to the limitations of the communication protocol, which is a custom-developed component of the system. However, there is a potential for using the da Vinci robot at a greater distance, which has been proved by some limited experiments. One of these includes the collaborative telerobotic surgery initiation by DARPA in 2005, when several modified da Vinci consoles were able to overtake the control from one another through the Internet [7]. In 2008, CSTAR (Canadian Surgical Technologies and Advances Robotics, London, ON) used the core network of Bell Canada for testing a modified, telesurgery-enabled version of the da Vinci. Altogether six successful pyeloplasty procedures were performed on porcine kidneys using telesurgery, with the slave manipulator located in Halifax, Nova Scotia, 1,700 kilometers away from the controllers [8]. The Plugfest was one of the most notable experiments in the past years in this research domain, allowing eight master devices to connect with six slave machines [9]. Simulated interventions such as peg transfer tasks (SAGES Fundamentals of Laparoscopic Surgery) were successfully supported for more than 24 hours, using the Interoperable Teleoperation Protocol (ITP) [10]. The recent advances in the reliability of the Internet network allows these high-level experiments to be executed safely, however, the Internet backbone infrastructure is becoming overloaded, with an immediate effect on the lag times [11]. In order to protect the patients in the future, some of the security issues need to be addressed, in accordance with IEC 80001-1:2010. When we discuss control over delayed channel, numerous safety and performance issues arise. Furthermore, there is a need for surgical training in the use of latency-affected master consoled, helping the operators learn how to tolerate latencies and other disturbing effects [12].

\section{Teleoperation Systems}

Just like every teleoperation system, master-slave surgical robots systems in general consist of three major components from the control and modeling point of view: the slave device, the master device and the communication system. In the field of telesurgery, slave-side modeling is extended with the phenomena of tooltissue interaction, the contact problem addressing the behavior of the tool and the soft/hard tissue under manipulation. The modeling of the components is essential 
for building a valid simulator for the system as a whole, creating the possibility of observation and analysis of control attributes, properties and behaviors. The models are subject to validation, both individually and as a part of the assembly. The schematic illustration of the functional components of a general telesurgical system is shown in Fig. 1.

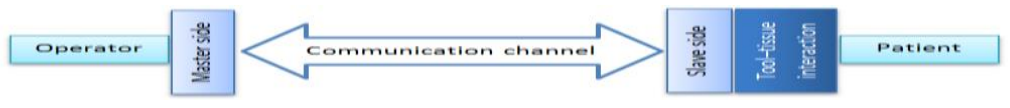

Figure 1

Block diagram of a general telesurgical system from the control point of view

\subsection{Communication System}

The communication system is the component responsible for data transfer, coding and decoding control signals and other tasks that make the communication between the master and slave devices possible at all levels. In general, the communication system includes a transmitter, a receiver and the communication medium. Signal quality and latency are both dependent from the subcomponents, individually. Besides quality issues, in telesurgical systems data loss is one of the most critical problems to be solved, which is, in general, the best handled by particular custom-designed protocols or the User Datagram Protocol (UDP) [11].

Humans have limited adaptability to time delay, it generally varies between $0.3-$ 0.5 seconds. In 2001, during the first trans-Atantic telesurgical intervention, the Zeus robot was in use, created by Computer Motion (Mountain View, CA) was recording a mean signal delay of $155 \mathrm{~ms}$ [14]. According to the measurements, $85 \mathrm{~ms}$ of lag appeared in signal transmission, while it took $70 \mathrm{~ms}$ to encode and decode the video streaming from the slave side. It is important to note that currently all surgical robots employed routinely in clinical applications are only providing visual and audio feedback. Haptic feedback is yet to be perfected due to stability issues. Data encoding would also increase the lag in long-distance communication.

Effects of time delay can be reduced with various control methods designed for latency-tolerance, therefore, there is an opportunity to bridge larger distances with these technologies. In order to achieve this, the system components must be modeled in a robust way, including all three main components of the teleoperation system. From the communication system approach, the master includes a controller and/or a human operator, subject to latencies, which is interconnected with the slave model through a high-delay medium. Using appropriate predictive controllers, the time delay can be partially alleviated in the deriving cascade setup, if the controller is well-tuned for both the master and slave systems [15]. 


\subsection{Master Model}

The master side is the component, where the human operator or a control device is located. In the past decades, several human models have been created to address the human behavior in the control loop. One of the most significant classical models is the crossover model, which was developed in the 1960s in order to model the behavior of fighter pilots during flight [16]. The crossover model is based on the time-dependent non-linear response of the human body, using a quasi-linear approximation. The complexity of the model highly depends on the precision of the task to be executed. However, there is a commonly used, reasonably good approximation:

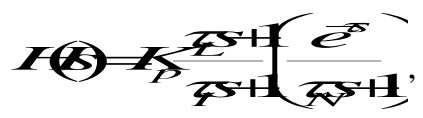

where the term in the brackets stands for the human physiological limitations, including the delay of the human reaction time. The time constant $\tau_{N}$ refers to the neuromuscular system, where the delay occurs. $K_{p}$ represents a static gain, while $\tau_{I}$ and $\tau_{L}$ express the time delay section and the control time constant, respectively. The trade-off for the simplicity of this model is that is does not represent other, detailed human attributes such as motivation, expertise and fatigue.

Another popular model of human operators was created by Ornstein [17]. A significant development compared to the crossover model is that the Ornstein model can also be applied in tracking tasks:

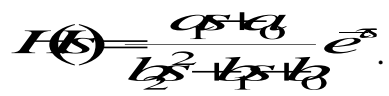

The coefficient values are determined by taking some physical attributes into account, such as velocity or static gain [18]. Due to the relatively high number of parameters, this model can become rather sophisticated, allowing one to describe neuromuscular effects or other dynamic response characteristics [19]. Furthermore, a large variety of sensory input noise can be modeled using a general signal disturbance, creating the possibility to include vision modeling [20].

In practice, the most commonly used non-linear human operator model is the GM/UMTRI car driver representation, developed at General Motors. The basis of this model is a general, quasi-linear UMTRI driver model [21]. These models have been widely used for the representation of master-slave type telesurgical tasks [22]. 


\subsection{Slave Side Models}

In telesurgical applications, functionality and safety requirements are, in general, higher than in other robotic applications. At the design stage, autonomous capabilities and proper mechanical modeling are important in satisfying these issues. In general, the kinematic model of a slave robot is described at a high level of precision in the details, enabling its integration in dynamic and kinematic models [23], [24]. These models, along with the appropriate image guidance and modeling, can largely increase the accuracy and safety of surgical interventions [25].

In robotic surgery, one of the most critical issues is the correct description of the model of the robot arm, the model of the manipulated tissue, and the behavior of these elements during manipulation tasks, on contact. This paper primarily focuses on soft tissue manipulation problems, while the issues involving hard tissues are in the focus of machining technology studies since drilling, milling and turning are exposed to great vibration and thus require stability issues. Most of the types of human soft tissues are inhomogeneous, viscoelastic, anisotropic and highly nonlinear materials. Therefore, object grabbing, cutting and other deformation analyses require significant effect.

\subsection{Soft Tissue Models}

Minimal Invasive Surgical (MIS) applications require an effective surgical training of the medical crew, which, in general, is achieved by virtual surgical training. Famaey and Sloten created a comprehensive review of the existing and most widely used soft tissue models that are integrated in MIS virtual surgical interfaces, introducing three major categories of tissue deformation and stress models [26]:

- Heuristic models (mass-spring-damper models)

- Continuum-mechanics based models

- Hybrid models

It is important to note that the complexity of the models within these categories varies on a wide scale, therefore, it is hard to compare them to each other. Due to their common use in finite element modeling, continuum-mechanics based models are considered to be the best approach for modeling realistic response to the task. In practice, continuum-mechanics based models require high computational capacity, whereas analytical solutions usually do not exist. The global behavior of soft tissues, particularly their viscoelastic nature can be modeled in a simpler way by using heuristic models. These consist of virtual mass, spring and damper elements, lumped together, ideal for describing simple manipulation tasks, such as grabbing, one-dimensional indentation or needle insertion. Due to the simplicity of 
this approach, analytical or semi-analytical solutions usually exist. The most commonly used heuristic models are shown in Fig. 2.

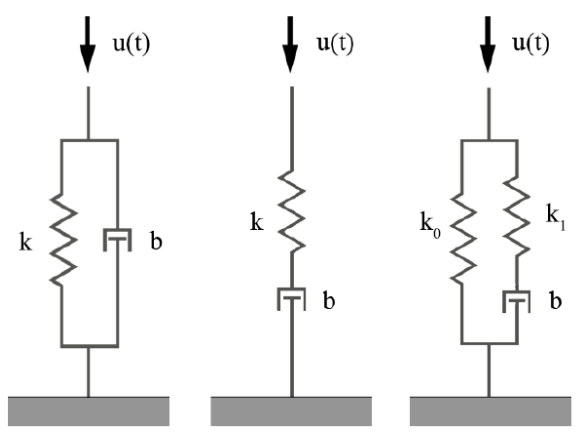

Figure 2

The most commonly used mechanical models of viscoelasticity:

a) Voigt model, b) Maxwell model, c) Kelvin model

Spring and damper elements combined provide a versatile tool for viscoelastic behavior description. In small scales, when the strain according to the applied force remains under $1 \%$, the use of purely linear, single-spring element models is justified. However, in practice, the complex geometry and the highly nonlinear behavior of soft tissues require advanced models. The modularity and the possibility of analytical solutions provide a great advantage by using heuristic soft tissue models. A detailed overview of the mass-spring-damper models have been presented in [28]. It was also shown that based on experimental data these models can provide realistic response for 1-DoF (Degree of Freedom) indentation tasks in the tissue relaxation phase, e.g. when the tissue is compressed at a high speed with a step-like input and is kept at that deformation until the transient force response settles down.

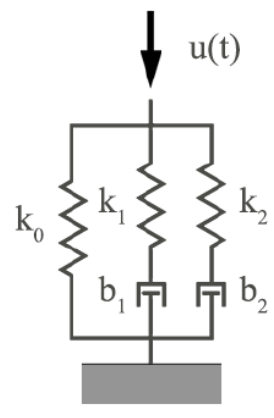

Figure 3

The proposed heuristic soft tissue model, the nonlinear Wiechert model 
The nonlinear model shown in Fig. 3 was used in [29] for the verification of liver indentation experiments, showing that an 8-parameter mass-spring-damper model can be used for the estimation of force response under 1-DoF indentation of soft tissues. The model is built up from a nonlinear spring element in a parallel connection with 2 nonlinear Maxwell-bodies, where the spring stiffness characteristics are represented by:

$$
k_{i}(x)=K_{i} e^{k_{i} x},
$$

where $x$ denotes the compression size of the spring elements, $K_{i}$ and $\kappa_{i}$, $i=1,2,3$ denote the spring characteristics constants, while $b_{1,2}$ are linear damping elements. If $x_{0}$ refers to a point on the soft tissue surface, $x_{1}$ and $x_{2}$ mark the position of two virtual points inside the Maxwell-bodies, the proposed nonlinear soft tissue model can be written in the following state-space form:

$$
\begin{aligned}
& x_{0}^{k}=u(t) \\
& x_{1}=\frac{1}{b_{1}} K_{1}\left(x_{0}-x_{1}\right) e^{\kappa_{1}\left(x_{0}-x_{1}\right)} \\
& \&=\frac{1}{b_{2}} K_{2}\left(x_{0}-x_{2}\right) e^{\kappa_{2}\left(x_{0}-x_{2}\right)},
\end{aligned}
$$

where $u(t)$ is the system input, representing the surface deformation velocity profile, while the system output, $y(t)$ stands for the force response of the system, i.e. the reaction force at the soft tissue surface:

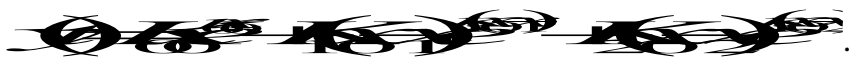

\section{Tool-Tissue Interaction Models}

In the past years, the topic of tool-tissue interaction modeling has gained interest due to the elevated demand for teleoperation and telemanipulation, as well for sophisticated control methods for advanced manipulators, which also require precise path planning for autonomous surgical tasks carried out by robots [30]. In telesurgery, one of the most addressed issues is the lack of force feedback in the existing telesurgical applications. This requires an extensive knowledge about the models of surgical tools, human tissues and their interaction. A comprehensive study on recent development in tool-tissue interaction modeling was presented by Misra et al. [31]. This survey focused on interaction types between models, 
primarily addressing continuum mechanics based structures and finite element methods. Takács et al. extended the area of interest for telesurgical applications, summarizing the most important models used in practice in Table 1 [32].

Table 1 summarizes the basic properties of the most commonly used tool-tissue interaction models in some of the most relevant robotic surgery applications. The analysis included the use case of the model; the tissue model type, (which all can be categorized into the listing in this section), the tool model, (which, in most cases goes down to a rigid model, as the stiffness values of soft tissues are orders of magnitudes lower than that of the surgical tools), the feedback type as the future of the surgical robotics applications is most likely connected (to the development of telesurgery), sensor types (for mounting miniature sensors on the surgical instruments is still a great challenge, which is mostly solved by placing the sensor elements away from the tool tips, using transformations based on tool model data for realistic data response), and model complexity (which is essential for the investigation of further usability in a particular application due to computation capacity and time limitations). 


\begin{tabular}{|c|c|c|c|c|c|c|c|}
\hline Model & Used for & Tissue model & Tool model & Feedback type & Sensors & Model complexity & Author \\
\hline 1 & $\begin{array}{l}\text { Analyzing } \\
\text { transparency under } \\
\text { slave-link and joint } \\
\text { flexibility }\end{array}$ & Rigid & $\begin{array}{l}\text { Linear } \\
\text { elastic }\end{array}$ & $\begin{array}{l}\text { Force feedback to } \\
\text { user's hand }\end{array}$ & $\begin{array}{l}\text { Position and } \\
\text { velocity sensors } \\
\text { at tool tip }\end{array}$ & $\begin{array}{l}\text { Varying, } \\
\text { determined by the } \\
\text { mechanical model } \\
\text { of the tool }\end{array}$ & $\begin{array}{l}\text { Tavakoli et } \\
\text { al. } 2009 \text { [33] }\end{array}$ \\
\hline \multirow{2}{*}{2} & \multirow{2}{*}{$\begin{array}{l}\text { Medical training } \\
\text { through simulation in } \\
\text { virtual reality }\end{array}$} & $\begin{array}{lr}\text { Mesh } & \text { based } \\
\text { FEA } & \text { model, } \\
\text { using } & \text { modal } \\
\text { analysis } & \end{array}$ & \multirow{2}{*}{ rigid } & \multirow{2}{*}{$\begin{array}{l}\text { Force and torque } \\
\text { feedback, collision } \\
\text { detection and } \\
\text { detection of multiple } \\
\text { tissue layers }\end{array}$} & \multirow{2}{*}{$\begin{array}{l}\text { Force and } \\
\text { position sensors } \\
\text { mounted on the } \\
\text { tool, held by the } \\
\text { user }\end{array}$} & $\begin{array}{l}\text { The complexity is } \\
\text { determined by the } \\
\text { level of system } \\
\text { reduction }\end{array}$ & \multirow{2}{*}{$\begin{array}{l}\text { Basdogan et } \\
\text { al. 2004 [34] }\end{array}$} \\
\hline & & $\begin{array}{l}\text { Real-time } \\
\text { method of finite } \\
\text { spheres }\end{array}$ & & & & $\begin{array}{l}\text { Simple, with } \\
\text { minimized } \\
\text { computational } \\
\text { effort }\end{array}$ & \\
\hline 3 & $\begin{array}{l}\text { Real-timer modeling } \\
\text { of soft tissue response } \\
\text { in computer } \\
\text { simulation, using } \\
\text { haptic device }\end{array}$ & $\begin{array}{l}\text { Meshless, } \\
\text { multi-layered } \\
\text { three-- } \\
\text { parameter } \\
\text { viscoelastic }\end{array}$ & rigid & $\begin{array}{lr}\text { Force } & \text { feedback } \\
\text { through Omega } 7 \\
\text { haptic devices, } \\
\text { visual feedback }\end{array}$ & $\begin{array}{l}\text { No sensor } \\
\text { mounted on the } \\
\text { instrument }\end{array}$ & $\begin{array}{l}\text { Advanced } \\
\text { mechanical model }\end{array}$ & $\begin{array}{l}\text { Bao et al. } \\
2013[35]\end{array}$ \\
\hline 4 & $\begin{array}{l}\text { Detecting lumps in } \\
\text { organ tissues (kidney, } \\
\text { liver, heart) }\end{array}$ & $\begin{array}{l}7 \quad \text { different } \\
\text { models, model } \\
\text { validation on } \\
\text { real tissues }\end{array}$ & rigid & $\begin{array}{l}\text { No feedback to } \\
\text { human user }\end{array}$ & $\begin{array}{l}1 \text { DoF force } \\
\text { feedback from } \\
\text { point-to-point } \\
\text { palpation }\end{array}$ & $\begin{array}{l}\text { Increased accuracy } \\
\text { with model } \\
\text { complexity }\end{array}$ & $\begin{array}{l}\text { Yamamoto } \\
2011[36]\end{array}$ \\
\hline 5 & $\begin{array}{l}\text { Detection of lumps in } \\
\text { prostate tissues, } \\
\text { definition } \\
\text { forbidden regions }\end{array}$ & $\begin{array}{l}\text { Manufactured } \\
\text { artificial tissue }\end{array}$ & rigid & $\begin{array}{l}\text { 3D visual feedback } \\
\text { generated with a } \\
\text { stereo-vision system }\end{array}$ & $\begin{array}{l}\text { Position, } \\
\text { velocity and } \\
\text { force sensors on } \\
\text { slave side }\end{array}$ & $\begin{array}{l}\text { Hunt-Crossley, a } \\
\text { complex but } \\
\text { accurate model }\end{array}$ & $\begin{array}{l}\text { Yamamoto } \\
\text { et al. } 2012 \\
{[37]}\end{array}$ \\
\hline 6 & Validation & Maxwell- & rigid & feedback & Force sensor at & Simple mechanical & Leong et al. \\
\hline
\end{tabular}




\begin{tabular}{|c|c|c|c|c|c|c|c|}
\hline & $\begin{array}{lr}\text { mechanical } & \text { model of } \\
\text { liver } & \text { tissue, } \\
\text { interaction } & \text { with } \\
\text { scalpel blade } & \end{array}$ & $\begin{array}{l}\text { Kelvin } \\
\text { viscoelastic, } \\
\text { mechanical } \\
\text { model }\end{array}$ & & human user & $\begin{array}{l}\text { the scalpel blade } \\
\text { holder, position } \\
\text { measurement. }\end{array}$ & model & $2013[27]$ \\
\hline 7 & $\begin{array}{l}\text { Force control on } \\
\text { robotic-assisted } \\
\text { surgery on beating } \\
\text { heart }\end{array}$ & $\begin{array}{l}\text { Kelvin- } \\
\text { Boltzmann } \\
\text { viscoelastic } \\
\text { mechanical } \\
\text { model }\end{array}$ & rigid & $\begin{array}{l}\text { No feedback to } \\
\text { human user }\end{array}$ & $\begin{array}{l}\text { Force sensor at } \\
\text { the end of } \\
\text { instrument, } \\
\text { position } \\
\text { measurement }\end{array}$ & $\begin{array}{l}\text { Simple mechanical } \\
\text { model }\end{array}$ & $\begin{array}{l}\text { Liu et al. } \\
2011[38]\end{array}$ \\
\hline 8 & $\begin{array}{l}\text { Simulation of needle } \\
\text { insertion in case of } \\
\text { prostate } \\
\text { brachytherapy }\end{array}$ & $\begin{array}{l}\text { Mesh-based } \\
\text { linear elastic } \\
\text { model }\end{array}$ & $\begin{array}{l}\text { Mesh-based } \\
\text { linear elastic }\end{array}$ & $\begin{array}{l}\text { No feedback to } \\
\text { human user }\end{array}$ & $\begin{array}{l}\text { No sensors } \\
\text { mounted on the } \\
\text { instrument }\end{array}$ & $\begin{array}{lr}\text { FEA model with } \\
\text { improved } & \text { re- } \\
\text { meshing } & \\
\text { performance } & \end{array}$ & $\begin{array}{l}\text { Goksel et al. } \\
2006 \text { [39] }\end{array}$ \\
\hline 9 & $\begin{array}{l}\text { Analytical model and } \\
\text { experimental } \\
\text { validation of needle } \\
\text { bending at insertion } \\
\text { into soft tissues }\end{array}$ & $\begin{array}{l}\text { Neo-Hookean } \\
\text { model } \\
\text { (hyperelastic), } \\
\text { rupture model }\end{array}$ & $\begin{array}{l}\text { Linear } \\
\text { elastic }\end{array}$ & $\begin{array}{l}\text { No feedback to } \\
\text { human user }\end{array}$ & $\begin{array}{l}\text { Unfiltered } \\
\text { camera data for } \\
\text { computation of } \\
\text { bending } \\
\text { curvature }\end{array}$ & $\begin{array}{l}\text { Complex } \\
\text { mechanical model, } \\
\text { extended use of } \\
\text { continuum- } \\
\text { mechanics }\end{array}$ & $\begin{array}{l}\text { Misra et al. } \\
2010[40]\end{array}$ \\
\hline 10 & $\begin{array}{l}\text { Analytical model of } \\
\text { tissue rapture due to } \\
\text { needle insertion into } \\
\text { porcine heart }\end{array}$ & $\begin{array}{l}\text { Modified } \\
\text { Kelvin } \\
\text { viscoelastic } \\
\text { model }\end{array}$ & rigid & $\begin{array}{l}\text { No feedback to } \\
\text { human user }\end{array}$ & $\begin{array}{l}\text { Tension/compre } \\
\text { ssion sensing } \\
\text { mounted on a } \\
\text { linear actuator }\end{array}$ & $\begin{array}{l}\text { Moderately } \\
\text { complex, using } 4 \\
\text { different models for } \\
\text { insertion events }\end{array}$ & $\begin{array}{l}\text { Mahvash et } \\
\text { al. } \\
2010 \text { [41] }\end{array}$ \\
\hline 11 & \begin{tabular}{lr}
\multicolumn{2}{l}{ Analytical mechanical } \\
model for cable- \\
driven & tools \\
interacting & with \\
artificial tissue &
\end{tabular} & $\begin{array}{l}\text { Use of artificial } \\
\text { tissue, only } \\
\text { contact force is } \\
\text { measured }\end{array}$ & $\begin{array}{l}\text { Lumped } 1 \\
\text { DoF model } \\
\text { with elastic } \\
\text { cable }\end{array}$ & $\begin{array}{l}\text { Feedback through } \\
\text { DC motor encoders }\end{array}$ & $\begin{array}{l}\text { Built-in } \\
\text { encoders near } \\
\text { the contact } \\
\text { point, force } \\
\text { gauge on the } \\
\text { cable }\end{array}$ & $\begin{array}{l}\text { Moderately } \\
\text { complex, } \\
\text { accounting for } \\
\text { many mechanical } \\
\text { properties }\end{array}$ & $\begin{array}{l}\text { Kosari et al. } \\
2012[42]\end{array}$ \\
\hline
\end{tabular}




\section{Controllers for Teleoperation Systems}

Along many different approaches, there has been a unified approach elaborated to resolve the control issues of telesurgical systems [43]. The design of controllers for teleoperation systems [14], [15], [44]-[50] is characterized by three unified features. These features will be pointed out as follows, along with details on the control system structures and controllers (algorithms) implemented in previous studies.

The first unified feature is the cascade control system structure given in Fig. 4. This control system structure points out the inner and the outer control loops. The inner loop plays its own role, in improvement of process dynamics and eventually compensation for some disturbances that act at that level. The inner controller is first designed and tuned, and the model of the inner control loop is processed such that to be used as a sub-system of the process in the design and tuning of the outer controller.

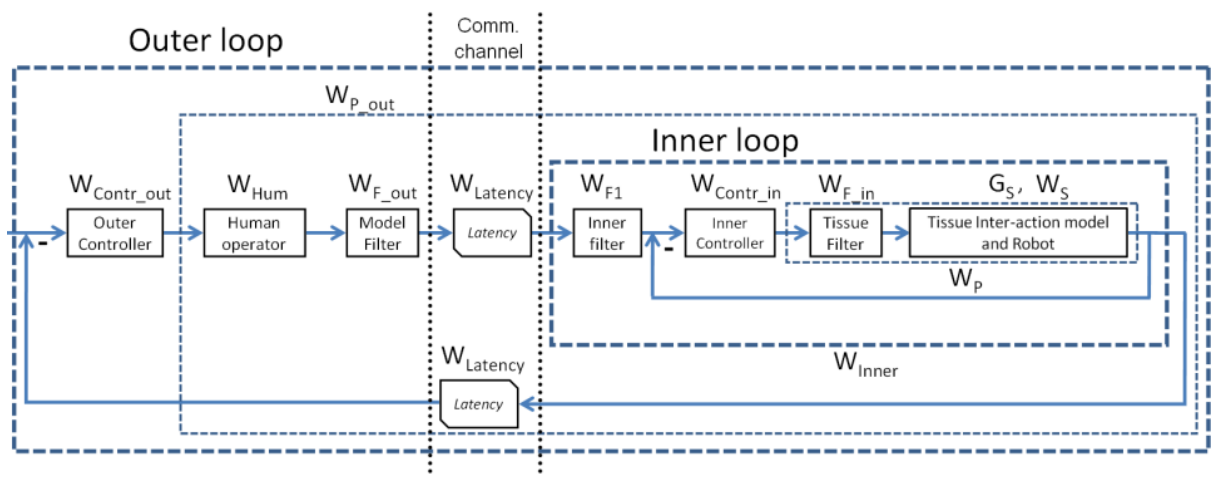

Figure 4

Cascade control system structure for teleoperation systems [41]

The second unified feature is the approximation of the time delays by first-order approximations in order to get transfer functions expressed in rational forms. This is advantageous because it enables the convenient design and tuning of the inner and outer controllers. In addition, Smith predictors can be further used for the same purpose.

The third unified feature is the use of the Extended Symmetrical Optimum (ESO) method [[51], [52]], to tune the parameters of the inner and outer PI and/or PID controllers. For example, using the inner PID controller transfer function:

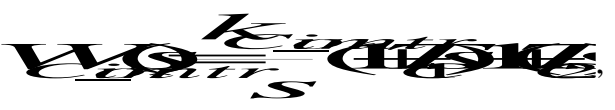

the tuning equations specific to the ESO method are: 


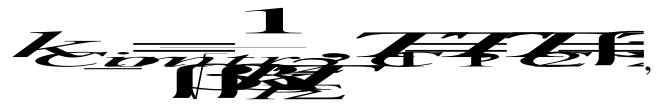

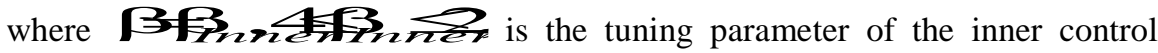
loop, which is selected by the control system designer. The control system performance is further improved by reference input filters. The inner filter is pointed out in Fig. 4 and the outer filter is not.

However, the approximation of large time delays is not generally feasible. But the ESO method is sufficiently robust to handle the model mismatches.

The fuzzy controllers are structured as low-cost PI-, PD- or PID-fuzzy controllers. The linear behavior specific to PI, PD and PID controllers is fuzzified and the modal equivalences principle is generally applied to obtain tune the parameters of the fuzzy controllers. The low-cost controllers are characterized by simple controller structures and design approaches adapted from several results for PI-fuzzy controllers [53]-[1].

A general view of telesurgery problems for space applications is offered in [45]. The process models are considered as: basic human models (with a detailed explanation of the crossover model), the robot model (with simple second-order manipulator model), and the tissue characteristics are given through Fung's exponential force-stretch ratio curve. The ESO method is applied to design the linear controllers in the cascade control system structure.

The same models as those used in [45] are presented in [46], but there is no tissue model. PI and PID controllers tuned by the ESO method and predictive controllers are considered. There are no simulation results in [45] and [46].

The process models described in [46] are used in [44] as well. The time delays re handled in several ways using: empirical Ziegler-Nichols method (tested by simulation results), the ESO method (tested by simulation results), and PID-fuzzy controllers for both the inner and outer loops of the cascade control system structure (without simulation results).

An explanation of cascade control with the requirements is presented in [47]. An explanation of the Smith predictor, using a general open-loop stable transfer function is also given. The controller tuning by Kessler's empirical methods and the ESO method is explained, and the limitations are pointed out. Simulation results are given for Kessler's method employed with Smith predictor for large latencies, and the model parameters are not included.

A four-step design and tuning approach is suggested in [48], and it is accompanied by the detailed explanation of the cascade control system and of the controller design and tuning for both loops using the ESO method. A third-order model for the inner loop (slave robot) and a first-order time-delayed model for human user are used. The digital controllers are obtained using Tustin's method by digitizing 
the continuous-time controllers. A PID-fuzzy controller is designed as the outer loop controller. Simulation results are included.

Overviews of the Takagi-Sugeno PID-fuzzy controllers, with a detailed theoretical background, and of cascade control systems and their role are carried out in [15]. The third-order slave robot model and the first-order time-delayed model for human user with Padé approximation are used. The controller design and tuning steps of the Takagi-Sugeno PID-fuzzy controller are presented in relation with the ESO method and the modal equivalences principle. A set of simulation results for a case study highlights the fuzzy control system performance improvement.

An overview of medical telerobotics in space is conducted in [49]. The controller design using Kessler's and ESO method are designed using a second-order timedelayed human operator model and a third-order slave robot model. Controller design steps for both the inner and outer loops of the cascade control system structure are given. Simulation results focusing the robustness of Kessler's method in terms of time delay are given.

An overview of the concept of telehealth is presented in [14] along with an introduction of the widely-used human operator and slave robot models. Fung's exponential force-stretch ratio is employed for the tissue model. An overview of the controller design solutions is also presented, with focus on linear control approaches designed by the ESO and on fuzzy control approaches in terms of Takagi-Sugeno PID-fuzzy controllers. The fuzzy control system structures are tested by simulation.

An overview of the components of telesurgical systems and the current difficulties is given in[50]. Using a third-order slave robot model and the cascade control system structure, the outer loop Takagi-Sugeno PID-fuzzy controller are designed using an approach based on Linear Matrix Inequalities (LMIs). The LMIs are derived such that to guarantee the stability of the fuzzy control system. Simulation results are given for the proposed design approach.

Using the outer PID controller with the transfer function:

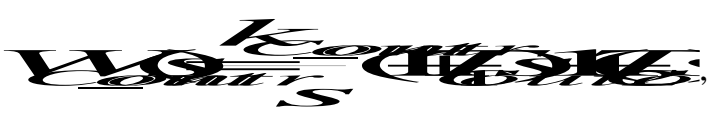

the series structure of the Takagi-Sugeno PID-fuzzy controller is implemented as the series connection of PI- and PD-fuzzy controller. This leads to the low-cost design and tuning of the PID-fuzzy controller that results from the fuzzification of the linear PI and PD controllers obtained from the decomposition: 


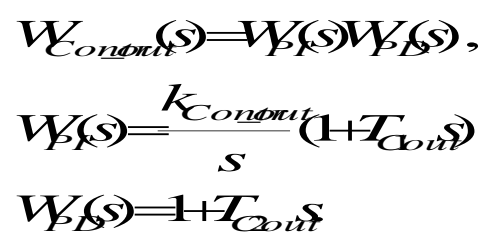

The transfer function can also be decomposed using a parallel structure. The parallel structure has more flexibility. Both PID- fuzzy controller structures, serial and parallel, can be fuzzified partially by keeping some linear components.

\section{Discussion}

In the past years, telesurgery has become the focus of modern medicine, spreading onto several fields of science, including control engineering, informatics, biotechnology, medicine and many more. One of the most important roles of telesurgery is to synthesize these areas, creating a complex field of study, directly linked to applications. These require a solid foundation from the engineering point of view. This paper summarized the major components of telesurgical systems, presenting difficulties, challenges, approaches, methods and proposed solutions to the emerging control engineering problems. It is discussed, why mathematical modeling of these components individually and together as a whole is crucial in order to fully understand the behavior of these complex systems. It is important to note that whereas the mentioned models and approaches may differ from each other fundamentally, it is not their validity, but their applicability for the specific task that should be considered, when choosing the right model for a given problem.

Besides the most widely used human operator and slave robot models, a detailed table has been presented, listing some of the most relevant approaches to tooltissue interaction modeling. An overview of the most important control methods for teleoperation systems has also been presented, extending the scope of this paper to real-life applications. Based on the discussed topics, an approach for modeling a complete telesurgical system was proposed. Future work includes the detailed investigation of each component, addressing both applicability and validity, and the integration of the listed components, applying the discussed control methods on the proposed models, verified by simulations and experiments.

\section{Acknowledgement}

This work was supported by the program "Partnerships in priority areas - PN II", implemented with the support of MEN - UEFISCDI, project ADCOSBIO no. 211/2014, PN-II-PT-PCCA-2013-4-0544. Tamás Haidegger is a Bolyai Fellow of the Hungarian Academy of Sciences. This work has been supported by ACMIT 
(Austrian Center for Medical Innovation and Technology), which is funded within the scope of the COMET (Competence Centers for Excellent Technologies) program of the Austrian Government.

\section{References}

[1] T. Haidegger, "Surgical Robot Prototyping-System Development, Assessment and Clearance," ch. 10 in T. Sobh and X. Xiong, Eds. Prototyping of Robotic Systems: Applications of Design and Implementation, IGI Book, Bridgeport, CT, pp. 288-326, 2012

[2] T. Haidegger, J. Sándor and Z. Benyó, "Surgery in Space: the Future of Robotic Telesurgery,” Surgical Endoscopy, Vol. 25, Issue: 3, pp. 681-690, 2011

[3] Mars One press release: "78,000 sign up for one-way mission to Mars" http://mars-one.com; May 7, 2013

[4] M. Hoeckelmann, I. J. Rudas, P. Fiorini, F. Kirchner and T. Haidegger, "Current Capabilities and Development Potential in Surgical Robotics," International Journal of Advanced Robotic Systems, p. 1, 2015

[5] S. Jordán, Á. Takács, I. Rudas and T. Haidegger, "Modelling and Control Framework for Robotic Telesurgery," in proc. of the $3^{\text {rd }}$ Joint Workshop on New Technologies for Computer/Robot Assisted Surgery (CRAS), Verona, 2013, pp. 89-92

[6] "da Vinci Products FAQ". http://phx.corporateir.net/phoenix.zhtml?c=122359\&p=irol-faq\#22324. Intuitive Surgical. Accessed on 7 July, 2015

[7] E. Flynn, "Telesurgery in the United States". Journal of Homeland Defense, Vol. 6, pp. 24-28, 2005

[8] C. Nguan, B. Miller, R. Patel et al.,"Preclinical Remote Telesurgery Trial of a da Vinci Telesurgery Prototype," International Journal of Medical Robotics and Computer Assisted Surgery, Vol. 4, pp. 304-309, 2008

[9] H. H. King, B. Hannaford, K.-W. Kwok, G.-Z. Yang, P. Griffiths, A. Okamura et al., "Plugfest 2009: Global Interoperability in Telerobotics and Telemedicine," in proc. of the IEEE International Conference on Robotics and Automation (ICRA), Anchorage, pp. 1733-1738, 2010

[10] N. J. Soper and G. M. Fried, "The Fundamentals of Laparoscopic Surgery," Journal of Gastrointestinal Surgery, Vol. 12, No. 4, pp. 624-628, 2008

[11] AT\&T, "NGlobal Network Latency Averages". Available: ipnetwork.bgtmo.ip.att.net/pws/global_network_avgs.html, 2013

[12] J. Sándor, B. Lengyel, T. Haidegger, G. Saftics, G. Papp, Á. Nagy and Gy. Wéber, "Minimally Invasive Surgical Technologies: Challenges in 
Education and Training: Minimally Invasive Surgical Technologies," Asian Journal of Endoscopic Surgery, Vol. 3, No. 3, pp. 101-108, May 2010

[13] S. Butner and M. Ghodoussi, "Transforming a Surgical Robot for Human Telesurgery," IEEE Transactions on Robotics and Automation, Vol. 19, No. 5, pp. 818-824, 2003

[14] T. Haidegger, L. Kovács, R.-E. Precup, B. Benyó, Z. Benyó and S. Preitl, "Simulation and Control for Telerobots in Space Medicine," Acta Astronautica, Vol. 81, No. 1, pp. 390-402, 2012

[15] R.-E. Precup, T. Haidegger, L. Kovács, A. S. Paul, S. Preitl and Z. Benyó, "Fuzzy Control Solution for Telesurgical Applications," Applied and Computational Mathematics. An International Journal (ACM), Vol. 11, No. 3, pp. 378-397, 2012

[16] R. A. Hess and A. Modjtahedzadeh, "A Control Theoretic Model of Driver Steering Behavior," IEEE Control Systems Magazine, Vol. 10, No. 5, pp. 38, 1990

[17] D. L. Kleinman, S. Baron and W. H. Levison, "An Optimal Control Model of Human Response Part I: Theory and Validation". Automatica, Vol. 6, No. 3, pp. 357-369, 1970

[18] G. N. Ornstein, "The Automatic Analog Determination of Human Transfer Function Coefficients." Medical Electronics and Biological Engineering, Vol. 1, No. 3, pp. 377-387, 1963

[19] C. C. MacAdam, "Understanding and Modeling the Human Driver". Vehicle System Dynamics, Vol. 40, No. 1-3, pp. 101-134, 2003

[20] R. G. Costello and T. J. Higgins, "An Inclusive Classified Bibliography Pertaining to Modeling the Human Operator as an Element in an Automatic Control System," IEEE Transactions on Human Factors in Electronics, Vol. HFE-7, No. 4, pp. 174-181, Dec. 1966

[21] C. C. MacAdam, "Development of a Driver Model for Near/At-Limit Vehicle Handling”, Technical report, UMTRI-2001-43. Sponsored by the General Motors Corporation, pp. 1-122, 2001

[22] J. H. Chien, M. M. Tiwari, I. H. Suh, D. Oleynikov and K.-C. Siu, "Accuracy and Speed Trade-Off in Robot-assisted Surgery," International Journal of Medical Robotics Assisted Surgery, Vol. 6, No. 5, pp. 324-329, 2010

[23] L. W. Sun, F. Van Meer, Y. Bailly and C. K. Yeung, "Design and Development of a Da Vinci Surgical System Simulator," in proc. of the IEEE International Conference on Mechatronics and Automation (ICMA), pp. 1050-1055, 2007

[24] A. A. Syed, X. G. Duan, X. Kong, M. Li, Y. Wang and Q. Huang, "6-DOF Maxillofacial Surgical Robotic Manipulator Controlled By Haptic Device," 
in proc. of the $9^{\text {th }}$ Intl. Conf. on Ubiquitous Robots and Ambient Intelligence (URAI 2012), Daejeon, pp. 71-74, 2012

[25] L. Pelyhe, and P. Nagy. "Relative Visibility of the Diagnostic Catheter." Acta Polytechnica Hungarica Vol. 11, No. 10, pp. 79-95 (2014)

[26] N. Famaey and J. Vander Sloten, "Soft Tissue Modelling for Applications in Virtual Surgery and Surgical Robotics", Computer Methods in Biomechanics and Biomedical Engineering, Vol. 11, no. 4, pp. 351-366, 2008

[27] F. Leong, W. Huang and C. Chui, "Modelling and Analysis of Coagulated Liver Tissue and its Interaction with a Scalpel Blade," Medical and Biological Engineering Computing, Vol. 51, pp. 687-695, 2013

[28] Á. Takács, J. K. Tar, T. Haidegger and I. J. Rudas, “Applicability of the Maxwell-Kelvin Model in Soft Tissue Parameter Estimation," in proc. of the IEEE $12^{\text {th }}$ Intl. Symp. on Intelligent Systems and Informatics (SISY), 2014, pp. 115-119

[29] Á. Takács, P. Galambos, I. J. Rudas and T. Haidegger, "Nonlinear Soft Tissue Models and Force Control for Medical Cyber-Physical Systems," in proc. of the IEEE International Conference on Systems, Man and Cybernetics, 2015 (accepted)

[30] I. Bíró and G. Fekete. "Approximate Method for Determining the Axis of Finite Rotation of Human Knee Joint." Acta Polytechnica Hungarica, Vol. 11, No. 9, pp. 61-74, 2014

[31] S. Misra, K. T. Ramesh and Allison M. Okamura, "Modeling of ToolTissue Interactions for Computer-based Surgical Simulation: A Literature Review," Presence: Teleoperators and Virtual Environments, Vol. 17, No. 5, pp. 463-491, 2008

[32] A. Takacs, S. Jordan, R.-E. Precup, L. Kovacs, J. Tar, I. Rudas and T. Haidegger, "Review of Tool-Tissue Interaction Models for Robotic Surgery Applications," in proc. of the IEEE 12 ${ }^{\text {th }}$ Intl. Symp. on Applied Machine Intelligence and Informatics (SAMI), 2014, pp. 339-344

[33] M. Tavakoli and R. D. Howe, "Haptic Effects of Surgical Teleoperator Flexibility," The International Journal of Robotics Research, Vol. 28, No. 10, pp. 1289-1302, 2009

[34] C. Basdogan, S. De, J. Kim et al., "Haptics in Minimally Invasive Surgical Simulation and Training", IEEE Computer Graphics and Applications, Vol. 24, No. 2, pp. 56-64, 2004

[35] Y. Bao, D. Wu, Z. Yan and Z. Du, “A New Hybrid Viscoelastic Soft Tissue Model based on Meshless Method for Haptic Surgical Simulation," The Open Biomedical Engineering Journal, Vol. 7, pp. 116-124, 2013 
[36] T. Yamamoto, "Applying Tissue Models in Teleoperated Robot-Assisted Surgery," PhD dissertation, Johns Hopkins University, Baltimore, MD. January, 2011

[37] T. Yamamoto, N. Abolhassani, S. Jung et al., "Augmented Reality and Haptic Interfaces for Robot-assisted Surgery," The International Journal of Medical Robotics and Computer Assisted Surgery, Vol. 8, pp. 45-56, 2012

[38] C. Liu, P. Moreira, N. Zemiti and P. Poignet, "3D Force Control for Robotic-assisted Beating Heart Surgery Based on Viscoelastic Tissue Model," in proc. of the Intl. Conf. of the IEEE Engineering in Medicine and Biology Society, pp. 7054-7058, 2011

[39] O. Goksel, S. E. Salcudean and S. P. DiMaio, "3D Simulation of NeedleTissue Interaction with Application to Prostate Brachytherapy", Computer Aided Surgery, Vol. 11, No. 6, pp. 279-288, 2006

[40] S. Misra, K. B. Reed, B. W. Schafer et al., "Mechanics of Flexible Needles Robotically Steered through Soft Tissue", The International Journal of Robotics Research, Vol. 29, No. 13, pp. 1640-1660, 2010

[41] M Mahvash and P. E. Dupont, "Mechanics of Dynamic Needle Insertion into a Biological Material," IEEE Transactions on Biomedical Engineering, Vol. 57, No. 4, pp. 934-943, 2010

[42] S. N. Kosari, S. Ramadurai, H. J. Chizeck and B. Hannaford, "Robotic Compression of Soft Tissue," in proc. of the IEEE International Conference on Robotics and Automation, St. Paul, MN, 2012. pp. 46544659

[43] Hokayem, Peter F., and Mark W. Spong. "Bilateral Teleoperation: An Historical Survey." Automatica, Vol. 42, No. 12, pp. 2035-2057, 2006

[44] T. Haidegger, L. Kovács, S. Preitl, R.-E. Precup, B. Benyó, Z. Benyó, "Controller Design Solutions for Long Distance Telesurgical Applications," International Journal of Artificial Intelligence, Vol. 6, No. S11, pp. 48-71, 2011

[45] T. Haidegger, L. Kovács, S. Preitl, R.-E. Precup, A. Kovács, B. Benyó and Z. Benyó, "Cascade Control for Telehealth Applications," Scientific Bulletin of the "Politehnica" University of Timisoara, Transactions on Automatic Control and Computer Science, Vol. 55 (69), No. 4, pp. 223232,2010

[46] T. Haidegger, L. Kovács, S. Preitl, R.-E. Precup, A. Kovács, B. Benyó and Z. Benyó, "Modeling and Control Aspects of Long Distance Telesurgical Applications," in proc. of the 2010 Intl. Joint Conf. on Computational Cybernetics and Technical Informatics (ICCC-CONTI), Timişoara, 2010, pp. 197-202 
[47] T. Haidegger, L. Kovács, H. Varga, S. Preitl, R.-E. Precup, B. Benyó and Z. Benyó, "Extended Symmetrical Optimum Combined with SmithPredictor for Telehealth Applications: a Case Study," in proc. of the $3^{\text {rd }}$ Intl. Conf. on Recent Achievements in Mechatronics, Automation, Computer Sciences and Robotics (MACRo), Tirgu-Mures, 2011, pp. 263-272

[48] R.-E. Precup, L. Kovács, T. Haidegger, S. Preitl, A. Kovács, B. Benyó, E. Borbely and Z. Benyó, "Time Delay Compensation by Fuzzy Control in the Case of Master-Slave Telesurgery," in proc. of the $6^{\text {th }}$ IEEE Intl. Symp. on Applied Computational Intelligence and Informatics (SACI), Timişoara, 2011, pp. 305-310

[49] T. Haidegger, L. Kovács, R.-E. Precup, S. Preitl, B. Benyó and Z. Benyó, "Cascade Control for Telerobotic Systems Serving Space Medicine," in proc. of the $18^{\text {th }}$ IFAC World Congress, Milano, 2011, pp. 3759-3764

[50] R.-E. Precup, T. Haidegger and L. Kovács, "Stable Hybrid Fuzzy Controller-based Architecture for Robotic Telesurgery Systems," International Journal of Computational Intelligence and Pattern Recognition, Vol. 1, No. 1, pp. 61-76, 2014

[51] S. Preitl and R.-E. Precup, "On the Algorithmic Design of a Class of Control Systems Based on Providing the Symmetry of Open-Loop Bode Plots," Scientific Bulletin of the "Politehnica" University of Timisoara, Transactions on Automatic Control and Computer Science, Vol. 41 (55), No. 2, pp. 47-55, 1996

[52] S. Preitl and R.-E. Precup, "An Extension of Tuning Relations After Symmetrical Optimum Method for PI and PID Controllers," Automatica, Vol. 35, No. 10, pp. 1731-1736, 1999

[53] S. Preitl and R.-E. Precup, Introducere in Conducerea Fuzzy a Proceselor, Editura Tehnica, Bucharest, 1997

[54] R.-E. Precup, S. Preitl, M. Balas and V. Balas, "Fuzzy Controllers for Tire Slip Control in Anti-lock Braking Systems," in proc. of the IEEE International Conference on Fuzzy Systems (FUZZ-IEEE 2004), Budapest, 2004, Vol. 3, pp. 1317-1322

[55] R.-E. Precup and S. Preitl, "PI-Fuzzy Controllers for Integral Plants tTo Ensure Robust Stability," Information Sciences, Vol. 177, No. 20, pp. 4410-4429, 2007

[56] R.-E. Precup, S. Preitl, M.-B. Radac, E. M. Petriu, C.-A. Dragos and J. K. Tar, "Experiment-based Teaching in Advanced Control Engineering," IEEE Transactions on Education, Vol. 54, No. 3, pp. 345-355, 2011

[57] R.-E. Precup, M. L. Tomescu, M.-B. Radac, E. M. Petriu, S. Preitl and C.A. Dragos, "Iterative Performance Improvement of Fuzzy Control Systems for Three Tank Systems," Expert Systems with Applications, Vol. 39, No. 9, pp. 8288-8299, 2012 